Review

\title{
IODINE DEFICIENCY IN LATVIA: CURRENT STATUS AND NEED FOR NATIONAL RECOMMENDATIONS
}

\author{
Ilze Konrāde ${ }^{1,2, \#}$, leva Kalere ${ }^{1}$, leva Strēle ${ }^{1}$, Marina Makrecka-Kūka ${ }^{1,3}$, Vija Veisa ${ }^{1}$, \\ Didzis Gavars ${ }^{4}$, Dace Rezeberga ${ }_{3}^{1}$, Valdis Pïrāgs ${ }^{5}$, Aivars, Lejnieks ${ }^{1,2}$, Uǵis Gruntmanis ${ }^{6}$, \\ Lolita Neimane ${ }^{1}$, Edgars Liepiṇš ${ }^{3}$, and Maija Dambrova ${ }^{1,3}$ \\ ${ }^{1}$ Rīga Stradinš̌ University, 16 Dzirciema Str., Rīga, LV-1007, LATVIA \\ ${ }^{2}$ Department of Endocrinology, Rīga East Clinical University Hospital, 2 Hipokrāta Str., Rīga, LV1038, LATVIA \\ ${ }^{3}$ Latvian Institute of Organic Synthesis, 21 Aizkraukles Str., Rĩga, LV-1006, LATVIA \\ ${ }^{4}$ E. Gulbis Laboratory, 366 Brīiības gatve, Rīga, LV-1006, LATVIA \\ ${ }^{5}$ University of Latvia, 19 Raina Blvd., Rīga, LV-1586, LATVIA \\ ${ }^{6}$ University of Texas Southwestern Medical Center, Dallas, Texas, USA \\ \# Corresponding author, drkonrade@ inbox.lv
}

Communicated by Aivars Lejnieks

\begin{abstract}
In the absence of a mandatory salt iodisation programme, two nationwide cross-sectional cluster surveys revealed persisting iodine deficiency among Latvian schoolchildren during the spring season and a noteworthy iodine deficiency in pregnant women in Latvia; these deficiencies warrant intervention. The consequences of mild-to-moderate iodine deficiency during pregnancy and lactation can adversely affect foetal brain development. Data from a Latvian population survey revealed the consumption of approximately $100 \mu \mathrm{g}$ of iodine per day through foods and iodised salt. Therefore, strategies to increase the consumption of iodine-containing products should be implemented, particularly for children. In addition, to meet the increased iodine requirement during pregnancy, pregnant women should take daily supplements containing $150 \mu \mathrm{g}$ iodine from the earliest time possible. All women of childbearing age should be advised to increase their dietary iodine intake by using iodised table salt and iodine-rich products: seafood, milk and milk products. For women with pre-existing thyroid pathologies, the medical decision should be considered on a case-by-case basis. Urinary iodine concentration monitoring among schoolchildren and pregnant women and neonatal thyrotropin registry analysis every five years would be an appropriate strategy for maintaining iodine intake within the interval that prevents iodine deficiency disorders.
\end{abstract}

Key words: iodine deficiency, children, pregnancy, iodine supplementation.

\section{INTRODUCTION}

Iodine is an essential micronutrient that is required for adequate thyroid hormone production. In adults, mild-to-moderate iodine deficiency appears to be associated with higher rates of the more aggressive subtypes of thyroid cancer and increased risk of diffuse goitre with the associated hypothyroidism, nontoxic goitre and toxic nodular goitre (Anonymous, 2008). Sufficient iodine intake is extremely important during pregnancy, breastfeeding and early childhood because even a mild iodine deficiency has the potential to impair optimal brain development (Pearce et al., 2013; Gowachirapant et al., 2009). According to the World Health Organisation (WHO) guidelines, the median urinary iodine concentration (UIC) in iodine-sufficient populations should be greater than $100 \mu \mathrm{g} / \mathrm{g} \mathrm{Cr}$, and less than $20 \%$ of the popu- lation can have a UIC below $50 \mu \mathrm{g} / \mathrm{g} \mathrm{Cr}$ (Bernal and Nunez, 1995). Accordingly, mild iodine deficiency is defined as a urinary iodine excretion of 50-99 $\mu \mathrm{g} / \mathrm{g} \mathrm{Cr}$, moderate deficiency as $20-49 \mu \mathrm{g} / \mathrm{g} \mathrm{Cr}$, and severe deficiency as less than $20 \mu \mathrm{g} / \mathrm{g}$ Cr (Ausó et al., 2004). Although the prevalence of iodine deficiency in Europe has decreased by almost $30 \%$ over the past decade, it still remains the leading cause of preventable intellectual impairment (Gowachirapant et al., 2009; Pearce et al., 2013) and is the primary motivation behind the current worldwide drive to eliminate iodine deficiency. The term iodine deficiency disorders (IDD) is used to define a group of diseases resulting from a relative loss of iodine in the diet, including those from multiple defects, which may be prevented by ensuring adequate intake (Anonymous, 2008; Huang et al., 2013). Despite good health indicators in the European Union, IDD prevention 
programmes have not been universally introduced, and parts of Europe have poor or incomplete access to iodised salt (Delange, 2002).

High-quality population data on iodine intake are required to assess the population status and to design strategies to correct deficiencies without introducing excessive intake. During the last five years, two nationwide cross-sectional cluster surveys on iodine nutrition have been performed in Latvia (Konrade et al., 2012; 2015; 2014); these data serve as the basis for national recommendations.

\section{IODINE SOURCES}

Iodine is obtained from the diet and is primarily absorbed by the gastrointestinal tract in the inorganic anionic form of iodide. Several studies have suggested that proximity to the sea and seaweed abundance are factors that support an adequate iodine supply, because seawater has the highest iodine concentration of nearly $58 \mu \mathrm{g} / \mathrm{L}$ (Pessah-Pollack et al., 2014). Because the Baltic Sea coast of Latvia extends for more than 500 kilometres, iodine is a largely overlooked nutrient in the country. The iodine cycling from seawater in many regions is slow and incomplete; thus, soils and drinking water are depleted of iodine, and populations in coastal regions can also be iodine deficient (Bath et al., 2013). In addition, foods of marine origin having the highest iodine concentration are not widely used in everyday meals in Latvia (Grīnberga et al., 2015). Most other foods and beverages have low iodine content (Table 1); thus, iodine fortification of table and industrial salt is the most convenient option. The advantage of iodised salt is that it is used by nearly all of society, irrespective of social and economic status.

According to the results of salt consumption analysis in 1999, less than $1 \%$ of all edible salt in Latvia was iodised (Selga et al., 2000); however, in 2014, the FinBalt study

Table 1

IODINE CONTENT IN 100 GRAMS OF FOOD (Dahl et al., 2009)

\begin{tabular}{lc}
\hline \multicolumn{1}{c|}{ Food } & Iodine $(\mu \mathrm{g} / 100 \mathrm{~g})$ \\
\hline Iodized salt & 2000 \\
Cod, baked & 130 \\
Lobster, boiled & 130 \\
Caviar & 117 \\
Sardine, in tomato sauce, canned & 67 \\
Salmon, farmed, raw & 44 \\
Shrimp or prawn, cooked & 37 \\
Egg & 39 \\
Milk* & $15-37$ \\
Yoghurt* & $18-24$ \\
Cheese (45\%, Edam, Cheddar) & $13-75$ \\
Potatoes & 2 \\
Fruits and berries & 2
\end{tabular}

* Content may vary according to the geographical area and the iodine content of the soil found an approximately 10-fold increase: $6.9 \%$ of men and $9.4 \%$ of women reported an intake of iodised salt (Grīnberga et al., 2015). In 2010-2011, the self-reported prevalence of regular iodised salt consumption by Latvian schoolchildren was similar, i.e., 10.2\% (Konrade et al., 2014).

Current efforts aimed at preventing iodine deficiency not only stipulate iodisation of all household table salts but also include other alternatives to increase the consumption of iodine-rich marine and additional iodine-fortified products (e.g., milk, mineral water) with standardised levels of iodine (Moleti et al., 2011). In several countries, cow milk is considered an important source of dietary iodine (Konrade et $a l ., 2012$ ), and associations between low urinary iodine excretion and a low intake of milk have been reported (Becker et al., 2006).

Foods such as milk and bread are sources of iodine due to the iodine-containing compounds used in agriculture and the use of iodised salt in food preparation (Speeckaert et al., 2011). In some countries, including the USA and Switzerland, the use of iodine-containing disinfectants or food supplements in cow fodder are determined by local regulations. However, no such regulations exist in Latvia. Consequently, statistical data are not routinely collected. We conducted a short survey of local farmers. We enrolled 37 farmers; 10 reported using iodophors, and 28 used iodine- fortified fodder. The median iodine content in the analysed samples was 546.9 (IQR 311.9; 759.2) $\mu \mathrm{g} / \mathrm{L}$ (Neimane, unpublished data). There was wide variation of iodine concentration ranging from 212.6 to $1298.7 \mu \mathrm{g} / \mathrm{L}$. Milk samples were collected in both winter and summer, and the iodine content was similar among seasons. The fat content of milk did not correlate significantly with iodine concentration. However, a larger sample size would be necessary to verify these results. Nevertheless, our recent study showed that the median UIC was significantly lower in women who reported only rare milk product consumption than in women who consumed approximately three servings of milk products daily (Konrade et al., 2015).

Dietary supplements are a significant source of iodine, especially during pregnancy. Our studies revealed that less than $20 \%$ of pregnant women reported the use of iodine-containing supplements, and only $6.8 \%$ used supplements with an iodine content of $\geq 150 \mu \mathrm{g}$; this supplementation resulted in a slightly higher median UIC compared with those of the group of women who did not use iodine-containing supplements and those who used supplements with an iodine content of $<100 \mu \mathrm{g}$ (Konrade et al., 2015). These findings indicate that iodine-containing supplements, dairy products and iodised salt are the most important iodine sources in Latvia.

\section{IMPORTANCE OF ADEQUATE IODINE NUTRITION}

Iodine deficiency occurs when the iodine intake does not meet the recommended levels. The term IDD is used to describe the consequences of iodine deficiency in a popula- 
tion; this deficiency may be prevented by ensuring adequate iodine intake (Anonymous, 2008; Rohner et al., 2014). In the adult population, iodine deficiency is associated with an increased rate of goiter, hyperfunctioning thyroid nodules, hypothyroidism, and diminished working ability and productivity. Regardless of age, there is also a latent risk of increased thyroid susceptibility to nuclear radiation. IDD is associated with a higher incidence rate of thyroid cancer and with an altered ratio of papillary to follicular neoplasia. In the state of iodine sufficiency, a significant predominance of papillary carcinoma is observed. This alteration means that, in fact, thyroid cancer subtypes shift towards more malignant forms (de Benoist et al., 2009).

However, the most significant effects result from insufficient iodine levels during pregnancy and the immediate postpartum period. A meta-analysis published in 2013 revealed that at age 5 , children lost 7.4 IQ points due to iodine deficiency during pregnancy (Bougma et al., 2013). Econometric models have established that this result not only is significant at the individual level but also affects society as a whole: a one-point decrease in IQ has been associated with a persistent $0.11 \%$ annual decrease in per capita gross domestic product (GDP). This effect is connected with an economic recession and translates into a decrease in productivity (Jones and Schneider, 2006). These substantial consequences result from even mild iodine deficiency, which disrupts the metabolism of thyroid hormones - a critical endocrine regulator of early brain development (Bernal and Nunez, 1995). The thyroid hormone regulates a specific gene underlying major neurodevelopmental events. This effect plays a significant role in neurogenesis, axon and dendrite formation, neuronal migration, synaptogenesis and myelination (Berbel et al., 1985; Berbel et al., 1994; Morreale De Escobar et al., 2000; Ausó et al., 2004; Cuevas et al., 2005). Furthermore, thyroid hormones are a key regulator of the basal metabolic rate and macronutrient metabolism (Oppenheimer et al., 1987).

\section{IODINE STATUS IN CHILDREN}

The first nationwide cross-sectional school-based cluster survey of IDD in Latvia was performed in 2000, when 587 schoolchildren were tested. The survey revealed a median UIC of $59 \mu \mathrm{g} / \mathrm{L}$, which was indicative of a mild iodine deficiency; severe iodine deficiency was observed in $19.2 \%$ $(\mathrm{n}=115)$ of the participants (Selga et al., 2000). Additionally, the Latvian neonatal thyrotropin (TSH) screening data from 2000-2002 provided evidence that Latvia is an iodine-deficient region (Gyurjyan et al., 2006).

A 10-year follow-up cross-sectional interseasonal schoolbased cluster survey was performed in October 2010 and April 2011 (Fig. 1). In addition, as a tool to monitor iodine deficiency during pregnancy, the Latvian Neonatal TSH screening data (prevalence of TSH $5 \mathrm{mIU} / \mathrm{L}$ ) from 31,274 newborns in 2009-2010 were analysed. The UIC was found to be at the lower end of the normal range $(107.3 \mu \mathrm{g} / \mathrm{g})$ (Konrade et al., 2014), which can be considered an im-

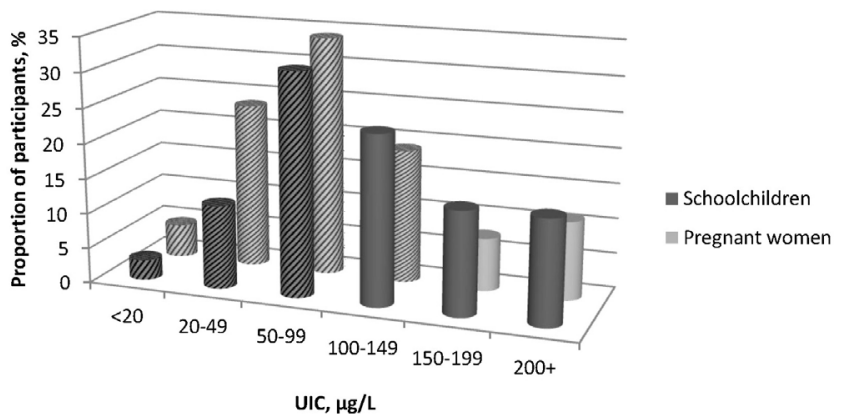

Fig. 1. Urinary iodine concentration (UIC) in Latvian schoolchildren (dark grey) and pregnant women (light grey). The striped columns represent UIC values below the normal range of the respective population, and the solid coloured columns are within the normal range. Cluster survey of schoolchildren performed in October 2010 and April 2011 (Konrade et al., 2014), and national survey of pregnant women carried out during the spring and autumn seasons in 2013 (Konrade et al., 2015).

provement compared with results of the previous nationwide cross-sectional school study (Selga et al., 2000). Similar to the results of other studies conducted in mild iodinedeficient regions of Europe (Als et al., 2003; Moreno-Reyes et al., 2011; Arrizabalaga et al., 2012), we found seasonal UIC fluctuations. In autumn, the UIC was at the lower end of the normal range $(129.7 \mu \mathrm{g} / \mathrm{g} \mathrm{Cr})$, but it was significantly lower during the spring sampling $(78.3 \mu \mathrm{g} / \mathrm{g} \mathrm{Cr}$ ) (Konrade et al., 2014). Interestingly, our study results showed fluctuations opposite to those of the previously cited publications that showed a higher UIC in spring. The data from the National Neonatal TSH Registry also confirmed seasonal differences in iodine levels and iodine deficiency in Latvia. Increased TSH levels were present in $8.7 \%$ of neonates, also indicating inadequate iodine nutrition and being in agreement with the measures of iodine status determined by UIC analysis (Konrade et al., 2014). Nevertheless, the result was significantly better than the rate of $16.5 \%$ found during the Latvian Neonatal TSH screening in 2000-2002 (Gyurjyan et al., 2006).

In conclusion, some degree of iodine deficiency is present in $49 \%$ of Latvian schoolchildren, especially in urban schools and in the Latgale and Vidzeme regions.

\section{IODINE STATUS IN PREGNANCY}

A study of pregnant women in Latvia found a median UIC of $80.8 \mu \mathrm{g} / \mathrm{g} \mathrm{Cr}$, indicating substantial iodine deficiency, and the data supported the notion that iodine deficiency already existed before pregnancy (Konrade et al., 2015). The median UIC was significantly higher in the second and third trimesters, which was attributed to the intake of iodine-containing supplements (Konrade et al., 2015). Contrary to the finding of no seasonality effect in the UIC values, the elevated TPO-Ab concentration was approximately two times higher in spring than in autumn (Konrade et al., 2015). In addition, we did not observe any association between UIC and elevated TPO-Ab values. Because more than $80 \%$ of the pregnant women had UICs lower than $150 \mu \mathrm{g} / \mathrm{g} \mathrm{Cr}$, the 
iodine supplementation was not expected to trigger thyroid autoimmunity, a result that has been observed in populations with UICs that were approximately three times greater (Guan et al., 2005). In countries such as Latvia, excessive iodine intake is unlikely, even with regular consumption of iodised salt at the WHO recommended amount of $5 \mathrm{~g}$ /day (Anonymous, 2014) and seafood once weekly.

\section{IODIZATION PROGRAMME-RELATED RISKS}

The WHO recommended daily dose of iodine is $150 \mu \mathrm{g}$ for adults, which is approximately three times the amount $(52 \mu \mathrm{g})$ of iodine that the thyroid must take up daily to remain in balance (Bürgi, 2010). Depending on the availability of iodine, a healthy thyroid gland is able to enhance or limit the use of iodine for thyroid hormone production for a limited period. However, epidemiological studies have linked even a cautious iodisation programme in countries with previous moderate or mild iodine deficiency to the development of hypothyroidism (Pedersen et al., 2007; Li et al., 2008). Furthermore, in almost all cases, this phenomenon had an autoimmune basis (Markou et al., 2001). In this context, previous animal model studies have connected induction of disease processes with thyroglobulin $(\mathrm{Tg})$ iodination, because observations showed that hypo-iodinated $\mathrm{Tg}$ did not activate $\mathrm{T}$ cells; however, increasing the $\mathrm{Tg}$ iodine content to even normal levels in vitro led to the antigenicity of the molecule (Barin et al., 2005). Iodide may epigenetically modify the $\mathrm{Tg}$ molecule and create iodinated neoantigenic determinants to which immune tolerance has not been established, or it may act via apoptotic/necrotic effects of thyrocytes, thus initiating the presentation of thyroid antigens that can activate T cells (Markou et al., 2001). Whether the pathological process will begin and which pathway will dominate depend on the genetic background.

A sudden increase in iodine intake in an iodine-deficient population may increase thyroid autoimmunity (Kahaly et al., 1998; Pedersen et al., 2007; 2011). One of the best and most studied examples is in Denmark, where iodine fortification of salt was introduced in 1998. In Aalborg, where the median UIC was $45 \mu \mathrm{g} / \mathrm{L}$ at the beginning of the programme, the incidence of hypothyroidism increased; in contrast, in Copenhagen, there was a mild iodine deficiency $(61 \mu \mathrm{g} / \mathrm{L})$ at the beginning of the programme, and the increase was not significant (Pedersen et al., 2007). Overt hypothyroidism occurred most often in young and middle-aged subjects with previous moderate iodine deficiency. Moreover, after five years of the public iodisation programme, the rate of TPO-Ab $30 \mathrm{U} / \mathrm{mL}$ in the Danish population increased from $14.3 \%$ to $23.8 \%$, and statistical significance was confirmed in multivariate regression models. In this study (Pedersen et al., 2007), the TPO-Ab increase was most pronounced in young women and for the lower antibody concentrations. Nonetheless, the possibility that this result was at least partly a transient phenomenon must be considered (Zimmermann et al., 2003); therefore, further studies are needed to evaluate the long-term effects and clinical consequences.

\section{AN OPTIMAL STRATEGY FOR THE DETECTION OF AUTOIMMUNE THYROID DISEASE IN PREGNANCY}

One solution for effective and safe iodine supplementation during pregnancy would be universal screening for autoimmune thyroid disease (AITD) with TSH and TPO-Ab detection at the first antenatal appointment. While the Latvian healthcare system is cutting laboratory testing expenses, such a recommendation would not gain regulatory acceptance. Thyroid, endocrine and obstetrics professional organisations have also prepared position statements on this issue; however, universal screening for thyroid disease during pregnancy is controversial, with strong proponents on both sides (Glinoer, 1998; Casey, 2006; Brent, 2007).

It is evident that thyroid disease has multiple adverse effects during pregnancy and the postpartum period, and in the developing foetus. These effects include miscarriage (Glinoer et al., 1991), preterm delivery (Stagnaro-Green et al., 2005), decreased intelligence quotient (Pop et al., 1999) and visual-motor deficiencies (Zoeller and Rovet, 2004) in the offspring, especially in women with elevated serum antithyroid antibody titres (Stagnaro-Green and Glinoer, 2004). Women with thyroid autoimmunity are also at an increased risk for postpartum thyroiditis (Muller et al., 2001) and the development of overt hypothyroidism in the future (Vanderpump et al., 1995). Despite the lack of effective strategies to decrease maternal and foetal complications for pregnant women with thyroid abnormalities (Negro et al., 2010), most professional associations recommend case finding for pregnant women who are identified as having a high risk for thyroid disease: family or personal history of autoimmune disease, history of neck irradiation, or previous miscarriages or preterm deliveries (Abalovich et al., 2007; Anonymous, 2007). Nonetheless, research data reveal that such practice may miss 30-50\% of the hypothyroid cases (Vaidya et al., 2007; Horacek et al., 2010). A literature review found analyses stating that universal screening of pregnant women for AITD is cost effective compared with no screening (Dosiou et al., 2008; Thung et al., 2009). Moreover, studies have shown that universal screening is also highly cost effective compared with high-risk screening only (Dosiou et al., 2012).

According to epidemiological study data, thyroidal autoimmunity affects approximately $11 \%$ of women of reproductive age (Hollowell et al., 2002), and this proportion was also observed in Latvia (Konrade et al., 2015). To improve obstetric outcomes and gain child IQ benefits in the setting of established iodine deficiency, a universal screening measuring TSH and TPO-Ab levels would allow personalised iodine supplementation recommendations.

\section{RECOMMENDATIONS}

In the absence of a mandatory salt iodisation programme, there is a persisting iodine deficiency among Latvian schoolchildren during the spring season and a noteworthy iodine deficiency in pregnant women in Latvia, which warrant intervention. 
The strategies for increasing the consumption of iodinecontaining products to approximately $150 \mu \mathrm{g}$ should be improved, particularly for children. Therefore, initiatives, such as the School Milk Programme and the use of iodinated salt in both school and household kitchens, will improve iodine nutrition.

Because mild to moderate iodine deficiency during pregnancy and the lactation period can adversely affect foetal brain development, WHO-UNICEF and ICCIDD advise an increase in the recommended daily dosage of iodine to 250 $\mu \mathrm{g} / \mathrm{day}$ for pregnant women and breastfeeding women and $150 \mu \mathrm{g} /$ day for women in the preconception period (Anonymous, 2008).

An adequate iodine status is important even before fertilisation and pregnancy. All women of childbearing age should be advised to increase their dietary iodine intake through the use of iodised table salt and dairy products and the consumption of seafood twice weekly.

Data from a survey of the Latvian population indicate that approximately $100 \mu \mathrm{g}$ of iodine per day is consumed through foods and iodised salt. To meet the increased iodine requirement in pregnancy, pregnant women should take a supplement containing $150 \mu \mathrm{g}$ of iodine daily from the earliest time possible.

Breast milk is an important source of iodine to maintain thyroid function in infants, who are highly dependent on maternal iodine nutrition during breast feeding. Therefore, in addition to dietary iodine sources, iodine supplementation of $150 \mu \mathrm{g}$ daily is recommended for breastfeeding women.

Whilst the importance of gestational iodine supplementation is undisputed, we believe that in mild-moderate iodinedeficient areas, such as Latvia, women considering conception who do not have adequate iodine intake through diet should be advised to consume iodine supplements for several months prior to pregnancy.

Iodine supplements may be contraindicated for women with certain pre-existing thyroid pathologies; the medical decision, which is taken on a case-by-case basis, is made by the physician.

UIC monitoring among schoolchildren and pregnant women and neonatal TSH registry analysis every five years will provide appropriate indicators for iodine intake to help keep UIC values within, but not higher than, the range that prevents IDD.

\section{REFERENCES}

Anonymous (2007). ACOG Committee Opinion No. 381. Subclinical hypothyroidism in pregnancy. Obstetr. Gynecol., 110, 959-960.

Anonymous (2008). Assessment of iodine deficiency disorders and monitoring their elimination. A guide for programme managers. Third edition. World Health Organization, UNICEF, ICCIDD. Available from: http://www.who.int/nutrition/publications/micronutrients/iodine_deficiency/9789241595827/en/ (accessed 15 May 2016).
Anonymous (2014). Sodium intake for adults and children. WHO. Available from: http://www.who.int/nutrition/publications/guidelines/sodium_intake/en/ (accessed 18 April 2016).

Abalovich, M., Amino, N., Barbour, L. A., Cobin, R. H., De Groot, L. J., Glinoer, D., Mandel, S. J., Stagnaro-Green, A. (2007). Management of thyroid dysfunction during pregnancy and postpartum: an Endocrine Society Clinical Practice Guideline. J. Clin. Endocrin. Metab., 92, S1-S47.

Als, C., Haldimann, M., Bürgi, E., Donati, F., Gerber, H., Zimmerli, B. (2003). Swiss pilot study of individual seasonal fluctuations of urinary iodine concentration over two years: Is age-dependency linked to the major source of dietary iodine? Eur. J. Clin. Nutr., 57, 636-646.

Arrizabalaga, J. J., Larrańaga, N., Espada, M., Amiano, P., Bidaurrazaga, J., Latorre, K., Gorostiza, E. (2012). Changes in iodine nutrition status in schoolchildren from the Basque Country. Endocrinología y Nutrición, 59, 474-84.

Ausó, E., Lavado-Autric, R., Cuevas, E., Escobar Del Rey, F., Morreale De Escobar, G., Berbel, P. (2004). A moderate and transient deficiency of maternal thyroid function at the beginning of fetal neocorticogenesis alters neuronal migration. Endocrinology, 145, 4037-4047.

Barin, J. G., Talor, M. V., Sharma, R. B., Rose, N. R., Burek, C. L. (2005). Iodination of murine thyroglobulin enhances autoimmune reactivity in the NOD.H2 mouse. Clin. Exper. Immunol., 142 (2), 251-259.

Bath, S. C., Steer, C. D., Golding, J., Emmett, P., Rayman, M. P. (2013). Effect of inadequate iodine status in UK pregnant women on cognitive outcomes in their children: Results from the Avon Longitudinal Study of Parents and Children (ALSPAC). Lancet, 27 (382), 331-337.

Becker, D. V., Braverman, L. E., Delange, F., Dunn, J. T., Franklyn, J. A., Hollowell, J. G., Lamm, S. H., Mitchell, M. L., Pearce, E., Robbins, J., Rovet, J. F. (2006). Iodine supplementation for pregnancy and lactation-United States and Canada: Recommendations of the American Thyroid Association. Thyroid, 16, 949-951.

de Benoist, B., McLean, E., Anderson, M. (2009). Iodine deficiency: The extent of the problem. In: Preedy, V. R., Burrow, G. N., Watson, R. R. (eds.). Comprehensive Handbook of Iodine. Academic Press, Elsevier, London, pp. 461-467.

Berbel, P., Guadańo-Ferraz, A., Angulo, A., Ramón Cerezo, J. (1994). Role of thyroid hormones in the maturation of interhemispheric connections in rats. Behav. Brain Res., 64, 9-14.

Berbel, P. J., Escobar del Rey, F., Morreale de Escobar, G., Ruiz-Marcos, A. (1985). Effect of hypothyroidism on the size of spines of pyramidal neurons of the cerebral cortex. Brain Res., 337, 217-223.

Bernal, J., Nunez, J. (1995). Thyroid hormones and brain development. Eur. J. Endocrinol., 133, 390-398.

Bougma, K., Aboud, F. E., Harding, K. B., Marquis, G. S. (2013). Iodine and mental development of children 5 years old and under: A systematic review and meta-analysis. Nutrients, 5, 1384-1416.

Brent, G. A. (2007). Editorial: Diagnosing thyroid dysfunction in pregnant women: Is case finding enough? J. Clin. Endocrinol. Metab., 92, 39-41.

Bürgi, H. (2010). Iodine excess. Best Practice Res. Clin. Endocrinol. Metab., 24 (1), 107-115.

Casey, B. M. (2006). Subclinical hypothyroidism and pregnancy. Obstetr. Gynecol. Surv., 61, 415-420.

Cuevas, E., Ausó, E., Telefont, M., Morreale De Escobar, G., Sotelo, C., Berbel, P. (2005). Transient maternal hypothyroxinemia at onset of corticogenesis alters tangential migration of medial ganglionic eminence-derived neurons. Eur. J. Neurosci., 22, 541-551.

Delange, F. (2002). Iodine deficiency in Europe and its consequences: An update. Eur. J. Nucl. Med. Mol. Imag., 29, 404-416.

Dosiou, C., Barnes, J., Schwartz, A., Negro, R., Crapo, L., Stagnaro-Green, A. (2012). Cost-effectiveness of universal and risk-based screening for au- 
toimmune thyroid disease in pregnant women. J. Clin. Endocrin. Metab., 97 (5), 1536-1546.

Dosiou, C., Sanders, G. D., Araki, S. S., Crapo, L. M. (2008). Screening pregnant women for autoimmune thyroid disease: A cost-effectiveness analysis. Eur. J. Endocrinol., 158, 841-851.

Glinoer, D. (1998). The systematic screening and management of hypothyroidism and hyperthyroidism during pregnancy. Trends Endocrinol. Metab., 9, 403-411.

Glinoer, D., Soto, M. F., Bourdoux, P., Lejeune, B., Delange, F., Lemone, M., Kinthaert, J., Robijn, C., Grun, J. P., de Nayer, P. (1991). Pregnancy in patients with mild thyroid abnormalities: Maternal and neonatal repercussions. J. Clin. Endocrinol. Metab., 73, 421-427.

Gowachirapant, S., Winichagoon, P., Wyss, L., Tong, B., Baumgartner, J., Melse-Boonstra, A., Zimmermann, M. B. (2009). Urinary iodine concentrations indicate iodine deficiency in pregnant Thai women but iodine sufficiency in their school-aged children. J. Nutr., 139, 1169-1172.

Grīnberga, D., Pudule, I., Velika, B., Gavare, I., Villeruša, A. (2015). Health Behaviour Among Latvian Adult Population, 2014. The Centre for Disease Prevention and Control, Latvia. 124 pp

Guan, H., Li, C., Li, Y., Fan, C., Teng, Y., Shan, Z., Teng, W. (2005). High iodine intake is a risk factor of post-partum thyroiditis: Result of a survey from Shenyang, China. J. Endocrinol. Investig., 28, 876-881.

Gyurjyan, R. H., Lugovska, R., Vevere, P., van der Haar, F. (2006). Newborn thyrotropin screening confirms iodine deficiency in Latvia. Eur. J. Clin. Nutr., 60, 688-690

Hollowell, J. G., Staehling, N. W., Flanders, W. D., Hannon, W. H., Gunter, E. W., Spencer, C. A., Braverman, L. E. (2002). Serum TSH, T(4), and thyroid antibodies in the United States population (1988 to 1994): National Health and Nutrition Examination Survey (NHANES III). J. Clin. Endocrinol. Metab., 87, 489-499.

Horacek, J., Spitalnikova, S., Dlabalova, B., Malirova, E., Vizda, J., Svilias, I., Cepkova, J., Mc Grath, C., Maly, J. (2010). Universal screening detects two-times more thyroid disorders in early pregnancy than targeted high-risk case finding. Eur. J. Endocrinol., 163, 645-650.

Huang, W., Peng, C., Huang, H., Zhang, J., Liu. J., Mao, L., Luo, R., Xiao, Y. (2013). Control of iodine-deficiency disorders following universal salt iodization in Shenzhen, China, 1997-2011. Food Nutr. Bull., 34 (3), 331-337.

Jones, G., Schneider, W.J. (2006). Intelligence, human capital, and economic growth: A Bayesian Averaging of Classical Estimates (BACE) approach. J. Econ. Growth, 11, 71-93.

Kahaly, G. J., Dienes, H. P., Beyer, J., Hommel, G. (1998). Iodide induces thyroid autoimmunity in patients with endemic goitre: A randomised, double-blind, placebo-controlled trial. Eur. J. Endocrinol., 139 (3), 290-297.

Konrade, I., Dambrova, M., Makrecka, M., Neimane, L., Strele, I., Liepinsh, E., Lejnieks, A., Vevere, P., Gruntmanis, U., Pīrāgs, V., Dambrova, M. (2012). Seasonal iodine deficiency in Latvian school children. Thyroid, 22, 1088-1089.

Konrade, I., Kalere, I., Strele, I., Makrecka-Kuka, M., Jekabsone, A., Tetere, E., Veisa, V., Gavars, D., Rezeberga, D., Pīrāgs, V., Lejnieks, A., Dambrova, M. (2015). Iodine deficiency during pregnancy: A national cross-sectional survey in Latvia. Public Health Nutr., 18 (16), 2990-2997.

Konrade, I., Neimane, L., Makrecka, M., Strēle, I., Liepinsh, E., Lejnieks, A., Vevere, P., Gruntmanis, U., Pīrāgs, V., Dambrova, M. (2014). A cross-sectional survey of urinary iodine status in Latvia. Medicina, 50 (2), $124-129$

Markou, K., Georgopoulos, N., Kyriazopoulou, V., Vagenakis, A. G. (2001). Iodine-Induced hypothyroidism. Thyroid, 11 (5), 501-510.

Moleti, M., Di Bella, B., Giorgianni, G., Mancuso, A., De Vivo, A., Alibrandi, A., Trimarchi, F., Vermiglio, F. (2011). Maternal thyroid function in different conditions of iodine nutrition in pregnant women exposed to mild-moderate iodine deficiency: An observational study. Clin. Endocrinol. (Oxford), 74, 762-768.

Moreno-Reyes, R., Carpentier, Y. A., MacOurs, P., Gulbis, B., Corvilain, B., Glinoer, D., Goldman, S. (2011). Seasons but not ethnicity influence urinary iodine concentrations in Belgian adults. Eur. J. Nutr., 50, 285-290.

Morreale De Escobar, G., Obregon, M. J., Escobar Del Rey, F. (2000). Clinical perspective: Is neuropsychological development related to maternal hypothyroidism or to maternal hypothyroxinemia? J. Clin. Endocrinol. Metab., 85, 3975-3987.

Muller, A. F., Drexhage, H. A., Berghout, A. (2001). Postpartum thyroiditis and autoimmune thyroiditis in women of childbearing age: Recent insights and consequences for antenatal and postnatal care. Endocrine Rev., 22, 605-630.

Negro, R., Schwartz, A., Gismondi, R., Tinelli, A., Mangieri, T., Stagnaro-Green, A. (2010). Universal screening versus case finding for detection and treatment of thyroid hormonal dysfunction during pregnancy. $J$. Clin. Endocrinol. Metab., 95, 1699-1707.

Oppenheimer, J. H., Schwartz, H. L., Mariash, C. N., Kinlaw, W. B., Wong, N. C., Freake, H. C. (1987). Advances in our understanding of thyroid hormone action at the cellular level. Endocrine Rev., 8, 288-308.

Pearce, E. N., Andersson, M., Zimmermann, M. B. (2013). Global iodine nutrition: Where do we stand in 2013? Thyroid, 23, 523-528.

Pedersen, I. B., Laurberg, P., Knudsen, N., Jørgensen, T., Perrild, H., Ovesen, L., Rasmussen, L. B. (2007). An increased incidence of overt hypothyroidism after iodine fortification of salt in Denmark: A prospective population study. J. Clin. Endocrinol. Metab., 92 (8), 3122-3127.

Pessah-Pollack, R., Eschler, D. C., Pozharny, Z., Davies, T. (2014). Apparent insufficiency of iodine supplementation in pregnancy. J. Women's Health (Larchmt), 23, 51-56.

Pop, V. J., Kuijpens, J. L., van Baar, A. L., Verkerk, G., van Son, M. M., de Vijlder, J. J., Vulsma, T., Wiersinga, W. M., Drexhage, H. A., Vader, H. L. (1999). Low maternal free thyroxine concentrations during early pregnancy are associated with impaired psychomotor development in infancy. Clin. Endocrinol. (Oxford), 50, 149-155.

Rohner, F., Zimmermann, M., Jooste, P., Pandav, C., Caldwell, K., Raghavan, R., Raiten, D. J. (2014). Biomarkers of nutrition for development: Iodine review. J. Nutr., 144, 1322S-1342S.

Selga, G., Sauka, M., Gerasimov, G. (2000). Status of iodine deficiency in Latvia Reconsidered: Results of nationwide survey of 587 schoolchildren in the year 2000. IDD Newsletter, 16, 54.

Speeckaert, M. M., Speeckaert, R., Wierckx, K., Delanghe, J. R., Kaufman, J. M. (2011). Value and pitfalls in iodine fortification and supplementation in the 21st century. Brit. J. Nutr., 106 (7), 964-973.

Stagnaro-Green, A., Chen, X., Bodgen, J. D., Davies, T. F., Scholl, T. O. (2005). The thyroid and pregnancy: A novel risk factor for very preterm delivery. Thyroid, 15, 351-357.

Stagnaro-Green, A., Glinoer, D. (2004). Thyroid autoimmunity and the risk of miscarriage. Best Practice Res. Clin. Endocrin. Metab., 18, 167-181.

Thung, S. F., Funai, E. F., Grobman, W. A. (2009). The cost-effectiveness of universal screening in pregnancy for subclinical hypothyroidism. Amer. $J$. Obstetr. Gynecol., 200 (267), e1-e7.

Vaidya, B., Anthony, S., Bilous, M., Shields, B., Drury, J., Hutchison, S., Bilous, R. (2007). Detection of thyroid dysfunction in early pregnancy: Universal screening or targeted high-risk case finding? J. Clin. Endocrinol. Metab., 92, 203-207.

Vanderpump, M. P., Tunbridge, W. M., French, J. M., Appleton, D., Bates, D., Clark, F., Grimley Evans, J., Hasan, D. M., Rodgers, H., Tunbridge, F., Yaing, E. T. (1995). The incidence of thyroid disorders in the community: A twenty-year follow-up of the Whickham Survey. Clin. Endocrinol. (Oxford), 43, 55-68. 
Zimmermann, M. B., Moretti, D., Chaouki, N., Torresani, T. (2003). Introduction of iodized salt to severely iodine-deficient children does not provoke thyroid autoimmunity: A one-year prospective trial in northern Morocco. Thyroid, 13 (2), 199-203.

Received 4 October 2016

Accepted in the final form 2 November 2017
Zoeller, R. T., Rovet, J. (2004). Timing of thyroid hormone action in the developing brain: Clinical observations and experimental findings. $J$. Neuroendocrinol., 16, 809-818.

\section{JODA DEFICĪTS LATVIJĀ: PAŠREIZĒJAIS STĀVOKLIS UN NEPIECIEŠAMĪBA PĒC JAUNĀM NACIONĀLAJĀM REKOMENDĀCIJĀM}

Apstākḷos, kad Latvijā nav obligātas sāls jodēšanas programmas, divi nacionālie šḳērsgriezuma klasteru apsekojumi atklājuši joda deficītu Latvijas skolēniem pavasara sezonā un būtisku joda deficītu grūtniecēm Latvijā; šis deficīts prasa iejaukšanos. Viegla un mērena joda deficīta sekas grūtniecības un barošanas ar krūti laikā var nevēlami ietekmēt augḷa smadzeṇu attīstību. Saskaṇā ar datiem no Latvijas iedzīvotāju apsekojuma dienā ar ēdienu un jodēto sāli tiek uzṇemti apmēram $100 \mu$ g joda. Tāpēc būtu nepieciešama stratēǵija jodu saturošu produktu patēriņa palielināšanai, it īpaši bērniem. Turklāt, lai sasniegtu palielināto joda pieprasījumu grūtniecības laikā, grūtniecēm pēc iespējas agrāk jāsāk lietot uztura bagātinātājus, kas satur vismaz $150 \mu \mathrm{g}$ joda. Visām reproduktīvā vecuma sievietēm jāiesaka palielināt joda uzṇemšanu ar ēdienu, lietojot jodēto sāli un produktus, kas satur daudz joda: jūras veltes, pienu un piena produktus. Sievietēm ar jau esošu vairogdziedzera slimību medicīniskais lēmums jāizdara katrā gadījumā atsevišķi. Joda koncentrācijas mērīšana urīnā skolēniem un grūtniecēm un jaundzimušo vairogdziedzeri stimulējošā hormona (TSH) reǵistra analīze ik pēc pieciem gadiem būtu piemērota stratēǵija joda nodrošinājuma uzturēšanai intervālā, kas novērš joda deficīta radītos traucējumus. 